\title{
Maastrichtian or Maestrichtian? A proposal to the Subcommission on Cretaceous Stratigraphy (IUGS, International Commission on Stratigraphy)
}

\author{
G.F.W. Herngreen ${ }^{1}$ \\ 1 Netherlands Institute of Applied Geoscience TNO/National Geological Survey, P.O. Box 80015, \\ NL-3508TA Utrecht, the Netherlands; e-mail: g.herngreen@nitg.tno.nl
}

Manuscript received: April 2000; accepted: August 2001

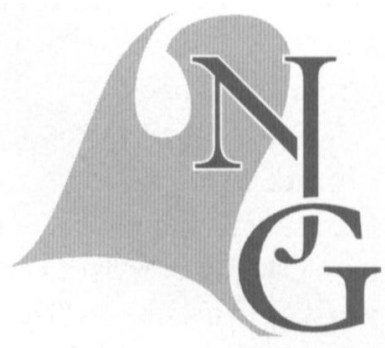

\begin{abstract}
This contribution deals with the dual spelling of the terminal Cretaceous Stage, the Maastrichtian or Maestrichtian. From a historical point of view and in agreement with the recommendations of the International Stratigraphic Guide (1st and 2nd editions) only Maestrichtian is justified. Nevertheless, the spelling Maastrichtian is proposed, or equivalents in other languages, because stratigraphic names should employ the spelling of place names in the country of their origin and, to be realistic, because Maastrichtian has been well established by its use in an overwhelming majority of the publications which have appeared during the last decades.
\end{abstract}

Keywords: Maastrichtian, spelling, usage

\section{Introduction}

A slightly different spelling of the terminal Cretaceous Stage name is frequently noted, either Maastrichtian or Maestrichtian. I drew attention to this dual usage as early as 1986 (Herngreen in Herngreen et al., 1986, p. 3 in particular). During the preparation of the present contribution paper, presented as a poster, for the Maastrichtian celebratory conference in November 1999, I consulted Dr G.S. Odin, chairman of the Maastrichtian Working Group, and Professor A. Salvador, past-chairman of the Subcommission on Stratigraphic Classification.

\section{Considerations regarding spelling}

Some forty-five years after the introduction of the 'système maestrichtien' (Maestrichtian Stage) by Dumont (1849), a second spelling, Maastrichtian, came into being. The following points, in part arguments pro or contra, regarding the spelling with 'aa' or 'ae' should be considered:

1 - the Subcommission on Upper Cretaceous Stratigraphy (IUGS) recommended in a report for the 22nd International Geological Congress at New Delhi (1964), to accept Maastrichtian as the correct spelling. However, this proposal was not discussed at the conference due to a cancellation of several meetings;

2 - the next meeting of the Subcommission, scheduled for August 21, 1968 on the occasion of the 23rd Congress at Prague, did not take place due to the Soviet invasion (Thiadens, 1970);

3 - as far as I know the proposal to spell Maastrichtian has never been effectuated between 1972 and the present;

4 - in Chapter 5 on 'Lithostratigraphic Units' (Hedberg, 1976, p. 41 ), it is proposed to maintain a spelling different from that of its geographic source, 
when it is/was repeatedly published. The same recommendation is found in Chapter 3 ('Definitions and Procedures', section 'Geographic Component of Names of Stratigraphic Units') in Salvador (1994, p. 20);

5 - both guides state concerning priority (Hedberg, 1976, p. 19; Salvador, 1994, p. 23) that, 'Priority alone does not justify displacing a well-established name by one not well known or only occasionally used'. As mentioned above, both guides also state concerning spelling, 'However, a stratigraphic name repeatedly published with a spelling different from that of its geographic source should nevertheless be retained';

6 - Rutot (1894) was the first to spell Maastrichtian for this time unit which was differentiated from the Senonian (Robaszynski in Robaszynski et al., 1985; Herngreen et al., 1986). Unfortunately and confusingly, part of the title of this paper was misspelt 'maestrichtiennes' in the well-known geological literature list of Jonker (1907). From the historical point of view it is clear that the spelling Maestrichtian has priority;

7 - in contrast to the opinion expressed by Herngreen et al. (1986), who claimed that the spelling Maestrichtian was uniformly used in over ten publications during more than 40 years since the introduction of this age/stage by Dumont (1849) (compare Table 1), it became clear after a thorough review of the literature that Binkhorst van den Binkhorst (1859) and Ubaghs (1879) had already used the expression 'Système maastrichtien de Dumont'. However, they considered it to be part of the Senonian;

8 - in the well-known 'Glossary of Geology' (Bates \& Jackson, 1987), Maestrichtian has priority, while it is added, 'Also spelled: Maastrichtian'. In the fourth edition (Jackson, 1997), however, we find, 'Maasstrichtian ........, occasionally spelled Maestrichtian' [underlining GFWH];

9 - preference to spell Maestrichtian is prompted by formal reasoning and based on the recommendations in the International Stratigraphic Guide (Hedberg, 1976; Salvador, 1994);

10 - in their comments to me, Odin and Salvador have raised several points in favour of the spelling Maastrichtian, as follows:

A - the spelling with 'aa' is the root of the city name in

Table 1. Use of the term 'Système maestrichtien' or equivalents in other languages, selected references.

\begin{tabular}{|c|c|c|}
\hline Author & (Short) title & Reference \\
\hline Dumont, A.H. 1849 & Rapport sur la carte géologique du Royaume & Bull. Acad. r. Belg. 16, 351-373 \\
\hline Dumont, A.H. 1852 & Carte géologique de la Belgique exécutée par ... & \\
\hline Bosquet, J. 1854a & $\begin{array}{l}\text { Les crustacés fossiles du terrain crétacé du } \\
\text { Limbourg }\end{array}$ & $\begin{array}{l}\text { Verh. Comm. geol. Beschr. Krt } \\
\text { Ned. 2, 11-138 }\end{array}$ \\
\hline $\begin{array}{l}\text { Bosquet, J. 1854b } \\
2,195-204\end{array}$ & Nouveau brachiopodes Système Maestrichtien & Verh. Comm. geol. Beschr. Krt \\
\hline Bosquet, J. 1859 & $\begin{array}{l}\text { Monographie des Brachiopodes fossiles du terrain } \\
\text { Crétacé supérieur ....... Limbourg }\end{array}$ & $\begin{array}{l}\text { Verh. Comm. geol. Beschr. Krt } \\
\text { Ned. 3, 1-50 }\end{array}$ \\
\hline Dewalque, G. 1868 & Prodrôme d'une description géologique de la Belgique & J.G. Carmanne (Bruxelles), 412 pp. \\
\hline Dewalque, G. 1868 & ditto (2nd edition) & H. Manceux (Bruxelles), $501 \mathrm{pp}$. \\
\hline Miquel, F.A.W. 1853 & $\begin{array}{l}\text { De fossiele planten van het Krijt in het hertogdom } \\
\text { Limburg }\end{array}$ & $\begin{array}{l}\text { Verh. Comm. geol. Beschr. Krt } \\
\text { Ned. 1, 33-56 }\end{array}$ \\
\hline Mourlon, M. 1880 & Géologie de la Belgique & F. Hayez (Bruxelles), 317 pp. \\
\hline $\begin{array}{l}\text { Rutot, A. \& Van den } \\
\text { Broeck, E. } 1888\end{array}$ & Géologie - Belgique et Pays Bas & Ann. géol. Univ. Paris 4, 505-510 \\
\hline Ubaghs, C. 1883 & La mâchoire de la Chelonia Hoffmanni.... & Ann. Soc. géol. Belg. 10, 25-35 \\
\hline Ubaghs, C. 1887 & $\begin{array}{l}\text { Quelques considérations sur .... Couches dites } \\
\text { Maestrichtiennes de Ciply }\end{array}$ & Bull. Soc. belge Géol. 1, 58-67 \\
\hline
\end{tabular}


the local language;

B - one has to yield to reality: all stratigraphic charts published in the last 40 years and a great majority of recent papers use Maastrichtian;

11 - of course it is agreed that the (present) spelling of the name of the city is Maastricht. However, for formal reasons the spelling Maestrichtian should be considered seriously;

12 - it is evident from the above-mentioned discrepancy (point 5) that there is a major difference between a Code (a law with very strict articles; e.g. the International Code of Botanical Nomenclature) and a Guide (with, occasionally loose, recommendations).

Robaszynski (in Robaszynski et al., 1985) argues that Rutot (1894) used the correct spelling Maastrichtian, 'as at the time of creation of the 'système' (1849), the type locality had been under Netherlands legislation since 1830 (at that time 'Maestricht' became 'Maastricht')'. In my view, this purported change in spelling appears to be a strange explanation, since as early as $1814 / 15$ the official reports of the town use the spelling Maastricht; only during the French occupation, up to the beginning of 1814 , was the name spelt Maestricht (C.P.F. Andreas, pers. comm. November 1985; confirmed by K. Schutgens, pers. comm. March 2000, both at Maastricht record-office). It should not be forgotten that the upper class in the Maastricht area spoke and wrote French up to the second half of the nineteenth century.

\section{Linguistic considerations}

New views on education and teaching were expressed in the Netherlands, following the 1795 revolution; amongst other things, this resulted in several education acts (1801, 1803 and 1806). In this connection, the first national and official orthographical regulation appeared, followed by a dictionary (Siegenbeek, 1804, 1805). The former spelling of long vowels with ae was abandoned and it was prescribed to spell aa. The French-speaking Belgians were not confronted at all with the changing of the Dutch spelling and continued to write Maestricht. This explains why Dumont wrote 'maestrichtien'; it was basically wrong already 150 years ago.

\section{Recommendation}

It is recommended to the Maastrichtian Working Group to make a formal proposal in their final report regarding the spelling of the Maa(e)strichtian. In spite of some historical arguments in favour of
Maestrichtian, the spelling of the city name in the Dutch language and reality, indeed, justify writing Maastrichtian. This proposal is in agreement with two general rules formulated by Moore (1952), that, 'Stratigraphic names which are spelled divergently in many publications shall be made uniform by adoption of the form accepted by a majority of later workers', and, 'Stratigraphic names should employ the spelling of the place names in the country of their origin rather than that of equivalent names in other languages'.

\section{Acknowledgements}

The author is indebted to Dr G.S. Odin (Département de Géologie sédimentaire, UPMC, Paris) and Professor A. Salvador (University of Texas, Austin) for their kind comments on an earlier version of the manuscript. The assistance of Messrs C.P.F. Andreas and $\mathrm{K}$. Schutgens (Maastricht record-office) is gratefully acknowledged. I thank Dr A.V. Dhondt (Institut royal des Sciences naturelles de Belgique, Brussels) for her helpful review.

\section{References}

Bates, R.L. \& Jackson, J.A. (Eds), 1987: Glossary of Geology (3rd ed.). American Geological Institute (Alexandria): $788 \mathrm{pp}$.

Binkhorst van den Binkhorst, J.-T., 1859. Esquisse géoloqique et paléontologique des couches crétacées du Limbourg, et plus spécialement de la craie tuffeau. Van Osch-America et Cie (Maastricht)/C. Muquardt (Bruxelles)/Schulz \& Thuillié (Paris): 268 pp.

Dumont, A., 1849. Rapport sur la carte géologique du Royaume. Bulletin de l'Académie royal des Sciences, des Lettres et des Beaux-Arts de Belgique 16:351-373.

Hedberg, H.D. (Ed.), 1976. International Stratigraphic Guide. A guide to stratigraphic classification, terminology, and procedure. John Wiley and Sons (New York): 200 pp.

Herngreen, G.F.W., Felder, W.M., Kedves, M. \& Meessen, J.P.M.T., 1986. Micropaleontology of the Maestrichtian in borehole Bunde, the Netherlands. Review of Palaeobotany and Palynology 48: 1-70.

Jackson, J.A., 1997. Glossary of Geology (4th ed.). American Geological Institute (Alexandria): $769 \mathrm{pp}$.

Jonker, H.G., 1907. Lijst van geschriften welke handelen over of van belang zijn voor de Geologie van Nederland (1734-1906). Verhandelingen van de Koninklijke Academie voor Wetenschappen (2) 13(2): 1-154.

Moore, R.C., 1952. Orthography as a factor in stability of stratigraphical nomenclature. State Geological Survey of Kansas, Bulletin 96 [Reports of Studies, Part 9]: 363-372.

Robaszynski, F., Bless, M.J.M., Felder, P.J., Foucher, J.-C., Legoux, O., Manivit, H., Meessen, J.P.M.Th. \& van der Tuuk, L.A., 1985. The Campanian-Maastrichtian boundary in the chalky facies close to the type-Maastrichtian area. Bulletin Centres de Recherches et d'Exploration et Production Elf-Aquitaine 9:1-113.

Rutot, A., 1894. Essai de synchronisme des couches maastrichti- 
ennes et sénoniennes de Belgique, du Limbourg hollandais et des environs d'Aix-la-Chapelle. Mémoires de la Société belge de Géologie, de Paléontologie et d'Hydrologie 8: 145-194.

Salvador, A. (Ed.), 1994. International Stratigraphic Guide. A guide to stratigraphic classification, terminology, and procedure (2nd ed.). International Union of Geological Sciences (Trondheim)/Geological Society of America (Boulder): $214 \mathrm{pp}$.

Siegenbeek, M., 1804. Verhandeling over de Nederduitsche spelling, ter bevordering van eenparigheid in dezelve. Allart (Amsterdam): xxvi $+387 \mathrm{pp}$.

Siegenbeek, M., 1805. Woordenboek voor de Nederduitsche spelling. Allart (Amsterdam): xii $+333 \mathrm{pp}$.

Thiadens, A.A., 1970. Subcommission on the Upper Cretaceous Stratigraphy. Report of the 23rd International Geological Congress, Prague, 1968, General Proceedings: 220-222.

Ubaghs, C., 1879. Description géologique et paléontologique du sol du Limbourg. J.J. Romen et fils (Roermond): 275 pp. 